\title{
Epidemiologic features of inflammatory bowel disease in Western Blacksea region of Turkey for the last 10 years: retrospective cohort study
}

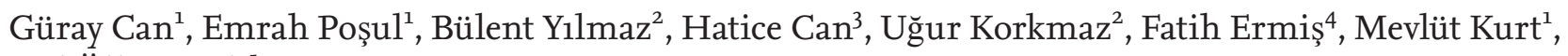
and Ülkü Dağl1 ${ }^{5}$

\begin{abstract}
${ }^{1}$ Department of Gastroenterology, Abant Izzet Baysal University Faculty of Medicine, Bolu; ${ }^{2}$ Department of Gastroenterology, Bolu Izzet Baysal State Hospital, Bolu; ${ }^{3}$ Department of Internal Medicine, Abant Izzet Baysal University Faculty of Medicine, Bolu; ${ }^{4}$ Department of Gastroenterology, Duzce University Faculty of Medicine, Duzce; ${ }^{5}$ Department of Gastroenterology, Baskent University Faculty of Medicine, Ankara, Turkey
\end{abstract}

Received: September 12, 2015 Revised : January 13, 2016 Accepted: October 10, 2017

\section{Correspondence to}

Güray Can, M.D.

Department of Gastroenterology, Izzet Baysal Educational and Research Hospital, Abant Izzet Baysal University Faculty of Medicine, Golkoy Campus, Bolu 14280, Turkey

Tel: +90-506-581-8944

Fax: +90-374-253-4559

E-mail: dr_guraycan@yahoo.com
Background/Aims: There are only a few epidemiological study about inflammatory bowel disease in the last 10 years in Turkey, especially in Western Blacksea region. In our study, we aimed to identify the changes in the incidence and the prevalence of inflammatory bowel disease in Western Blacksea region at the last 10 years.

Methods: Totally 223 patients with inflammatory bowel disease (160 ulcerative colitis, 63 Crohn's disease) were enrolled in the study followed up between 2004 to 2013 years. The epidemiological characteristics of patients were recorded.

Results: The prevalences were $12.53 / 10^{5}$ and $31.83 / 10^{5}$ for Crohn's disease and ulcerative colitis respectively. Mean annual incidences increased from $0.99 / 10^{5}$ and $0.45 / 10^{5}$ for ulcerative colitis and Crohn's disease (2004 to 2005 years) to $4.87 / 10^{5}$ and $2.09 / 10^{5}$ for ulcerative colitis and Crohn's disease respectively (2011 to 2013 years). While the prevalence was higher in urban areas in Crohn's disease $\left(12.60 / 10^{5}\right)$, it was higher in rural areas in ulcerative colitis $\left(36.17 / 10^{5}\right)$. In ulcerative colitis, mean annual incidences were $2.91 / 10^{5}$ and $2.86 / 10^{5}$ for urban and rural areas respectively. In Crohn's disease, they were $1.37 / 10^{5}$ and $1.08 / 10^{5}$ for urban and rural areas respectively.

Conclusions: The incidence of inflammatory bowel disease seems to increase in Western Blacksea region at the last 10 years. This increment is more prevalent in rural areas.

Keywords: Crohn disease; Epidemiology; Incidence; Prevalence; Colitis, ulcerative

\section{INTRODUCTION}

Inflammatory bowel disease (IBD) is a group of disorder that is characterized by the chronic inflammation in gastrointestinal tract of the genetically susceptible hosts who exposed to environmental risk factors [1-3]. Although, ethiological relation of IBD have been studied extensively with demographics, socioeconomic and geographic features, the pathogenesis of the disease remains unclear [3-6]. There is considerable geographic differences in the epidemiology of IBD all around the world. IBD is seen more frequently among Western community with high socioeconomic levels and better sanitary conditions $[7,8]$. The highest incidence is observed in Western Europe and North America [9,10]. Mean rates of incidence and prevalence in Western Europe and North America is $6 / 10^{5}$ and $150 / 10^{5}$ for Crohn's disease (CD) and $20 / 10^{5}$ and $200 / 10^{5}$ for ulcerative colitis (UC) respectively 
[11-14]. Whereas the developing countries demonstrated a recent increase in incidence and prevalence of IBD, it is stabilized in Western community. This contributes the closing gap between incindences of Western and Eastern population $[5,6,12,15]$. This increment in developing countries displays an association with industrialization and westernization of life style $[7,8]$. On the other hand, it can be said that ethnicity is effective on the incidence of UC and CD [16]. Though the higher incidence of IBD among Ashkenazic Jewish and Caucasians and the lower incidence in Far East and South Africa region suggest the genetic susceptibility, the increasing incidence in children of Asians who immigrated to developed countries shows the impact of environmental factors [5,9,17-20].

Turkey is a developing country according to Western countries which has a transition position between East and West in respect of socioeconomic level, sanitation, and industrialization. As the incidence of disease is not high as in the Western communities and, it is not low as in the Eastern communities, our country is a crossover between East and West in terms of IBD. There is several studies performed for the epidemiology of IBD in the last decade in Turkey [21-24]. Of these, the largest one was conducted by IBD Association between 2004-2006 all across the country over the web and comprised 2,398 patients [24]. Because of the heterogenity of ethnicity in Turkey, there are differences in incidence rates across regions. There is no epidemiologic data for IBD over 8 years period in Western Blacksea region which is a region that ethnically more homogenous. In our study, it is aimed to investigate the change in prevalence and incidence of UC and CD between 2004 and 2013.

\section{METHODS}

\section{Ethical statement}

The study was approved by Abant İzzet Baysal University Non-Interventional Clinical Studies Ethics Committee subsequent to planning (Protocol no: 2014/69-145, Date of approval: 06 Agust 2014). All the patients gave informed consent.

\section{Patients and data collection}

Our study was designed as multicentral, descriptive, retrospective, hospital based epidemiological study.
The Western Blacksea region is ethnically homogenous and has a relatively stabilized population structure. The total population is 502,580 and it is a sufficient size to evaluate an incidence and prevalence of the population. All residents of the region receive necessary health care service free by the coverage of government. There is three centers for the management of IBD patients with an adequate equipment and gastroenterologist. Even if IBD is diagnosed outside the tertiary center, all IBD patients were referred to these centers from primary and secondary care health services for the management and follow-up because there are IBD trained specialists, IBD multi-disciplinary management team (radiologist, pathologist, surgeon, nurse, and psychiatrist) and electronical follow-up system only in tertiary centers. Also, IBD drugs can be prescribed by only gastroenterologists. There is convenient local public transport for the access to study centers. All data obtained from the patients filled as electronically and hard copy.

Total 223 IBD patients over 15 years old, diagnosed by a gastroenterologist according to clinical, endoscopical, radiological, and histopathological criteria based on European Crohn's and Colitis Organisation guidelines [25,26], and followed up between 2004 to 2013 in Gastroenterology outpatient clinics of Abant İzzet Baysal University, Bolu İzzet Baysal State Hospital and Düzce University, were recruited to study. Of these, 160 (71.7\%) were diagnosed with UC and 63 (28.3\%) with CD. All the patients with UC and CD over 15 years old followed up at least 3 months after the diagnosis were included the study. Exclusion criterias were IBD patients under 15 years old, intermediate colitis, mental retardation and no participation to study. All recruited patients were followed up at least for 3 months and the diagnosis was confirmed. It is presumed that the study covers all of the patients in the region as there is no other gastroenterologist to follow-up the IBD patients out of these three centers in this region and all of the suspected patients are referred to these centers.

Clinical and sociodemographical features, age of diagnosis and the place of birthwere recorded from the files of the patients. The demographic information of the population over 15 years old at study region between 2004 and 2013 was provided from Turkish Statistical Institute. The incidence by years and the distribution of incidence and prevalence in 2013 by decennary age 
Table 1. Sociodemographical features of the patients with ulcerative colitis and Crohn's disease

\begin{tabular}{|c|c|c|c|c|}
\hline Variable & Ulcerative colitis & Crohn's disease & IBD & $p$ value $^{\mathrm{a}}$ \\
\hline Number & $160(71.7)$ & $63(28.3)$ & $223(100)$ & \\
\hline Sex & & & & 0.727 \\
\hline Male & $90(56.2)$ & $42(66.6)$ & $132(59.2)$ & \\
\hline Female & $70(43.8)$ & $21(33 \cdot 3)$ & $91(40.8)$ & \\
\hline Male/Female ratio & 1.28 & 2.00 & 1.45 & \\
\hline \multicolumn{5}{|l|}{ Age, yr } \\
\hline Male & $46.7 \pm 13.9$ & $45.1 \pm 14.6$ & $46.2 \pm 14.1$ & 0.549 \\
\hline Female & $45 \cdot 4 \pm 15 \cdot 3$ & $43.8 \pm 16.5$ & $45.1 \pm 15 \cdot 5$ & 0.669 \\
\hline Total & $46.1 \pm 14.5$ & $44.6 \pm 15.1$ & $46.0 \pm 14.3$ & 0.498 \\
\hline Place of birth & & & & 0.367 \\
\hline Bolu & $111(69.4)$ & $42(66.7)$ & $153(68.6)$ & \\
\hline Duzce & $29(18.1)$ & $12(19.0)$ & $41(18.4)$ & \\
\hline Others & $20(12.5)$ & $9(14 \cdot 3)$ & $29(13.0)$ & \\
\hline Place of live & & & & 0.261 \\
\hline Bolu & $121(75.6)$ & $46(73.0)$ & $167(74 \cdot 9)$ & \\
\hline Duzce & $31(19.4)$ & $14(22.2)$ & $45(20.2)$ & \\
\hline Others & $8(5.0)$ & $3(4.8)$ & $11(4 \cdot 9)$ & \\
\hline Environment & & & & 0.545 \\
\hline Urban & $93(58.1)$ & $40(63.5)$ & $133(59.6)$ & \\
\hline Rural & $67(41.9)$ & $23(36.5)$ & $90(40.4)$ & \\
\hline Marital status & & & & 0.296 \\
\hline Married & $140(87.5)$ & $50(79 \cdot 3)$ & $190(85.2)$ & \\
\hline Single & $18(11.2)$ & $12(19.0)$ & $30(13.4)$ & \\
\hline Widow/Divorced & $2(1.3)$ & $1(1.6)$ & $3(1.3)$ & \\
\hline \multicolumn{5}{|l|}{ Age of diagnosis, $\mathrm{yr}^{\mathrm{b}}$} \\
\hline Male & $41.5 \pm 13.2$ & $40.4 \pm 14.6$ & $41.2 \pm 13.6$ & 0.672 \\
\hline Female & $39.1 \pm 15.5$ & $39.1 \pm 14.6$ & $39.1 \pm 15.2$ & 0.991 \\
\hline Total & $40.5 \pm 14.2$ & $40.0 \pm 14.5$ & $40.3 \pm 14.3$ & 0.831 \\
\hline \multicolumn{5}{|l|}{ Family history } \\
\hline $1^{\circ}$ Relatives & $11(9.6)$ & $1(1.9)$ & $12(7.2)$ & 0.107 \\
\hline $2^{\circ}$ Relatives & $9(7.8)$ & o & $9(5 \cdot 4)$ & 0.058 \\
\hline Total & $20(17.4)$ & $1(1.9)$ & $21(12.6)$ & $0.004^{d}$ \\
\hline
\end{tabular}

Values are presented as number (\%) or mean $\pm \mathrm{SD}$.

IBD, inflammatory bowel diseases.

${ }^{\mathrm{a}}$ Chi-square test and Fisher exact test were used.

${ }^{\mathrm{b}}$ Independent Student $t$ test was used.

${ }^{\mathrm{c}}$ Data about IBD family history was complete in only 115 of 160 ulcerative colitis patients and 52 of 63 Crohn's disease patients.

${ }^{\mathrm{d}}$ Chi-square test and Fisher exact test were used. The rate of familiy history $\left(1^{\circ}\right.$ and $2^{\circ}$ relatives) was significantly higher in Crohn's disease than ulcerative colitis.

groups and gender were calculated. Also, the prevalence rate for urban and rural areas was determined.

\section{Statistical consideration}

The incidence rate was calculated by dividing the number of new cases to population under risk in that year. 
Table 2. The distribution of prevalences of ulcerative colitis and Crohn's disease by age groups in Western Blacksea region

\begin{tabular}{|c|c|c|c|c|c|c|c|c|c|}
\hline \multirow[t]{2}{*}{ Age, yr } & \multicolumn{3}{|c|}{$\begin{array}{l}\text { Upper than 15-year-old population } \\
\text { in Western Blacksea region in } 2013\end{array}$} & \multicolumn{3}{|c|}{$\begin{array}{c}\text { Ulcerative colitis } \\
\text { (prevalence/100,ooo person) }\end{array}$} & \multicolumn{3}{|c|}{$\begin{array}{c}\text { Crohn's disease } \\
\text { (prevalence/100,ooo person) }\end{array}$} \\
\hline & Female & Male & Total & Female & Male & Total & Female & Male & Total \\
\hline $15-24$ & 50,338 & 51,576 & 101,914 & $6(11.92)$ & $3(5.81)$ & $9(8.83)$ & $1(1.98)$ & 1 (1.93) & $2(1.96)$ \\
\hline $25-34$ & 49,113 & 50,645 & $99,75^{8}$ & $9(18.32)$ & $18(35 \cdot 54)$ & $27(27.06)$ & $8(16.29)$ & $13(25.66)$ & $21(21.05)$ \\
\hline $35-44$ & 46,043 & 47,336 & 93,379 & $25(54 \cdot 30)$ & $20(42.25)$ & $45(48.19)$ & $4(8.68)$ & $7(14.78)$ & $11(11.78)$ \\
\hline $45-54$ & 39,868 & 39,834 & 79,702 & $7(17 \cdot 55)$ & $22(55.23)$ & $29(36.38)$ & $4(10.03)$ & $7(17 \cdot 57)$ & $11(13.80)$ \\
\hline $55-64$ & 31,774 & 31,016 & 62,790 & $13(40.91)$ & $17(54.81)$ & $29(46.18)$ & $1(3.14)$ & $10(32.24)$ & $11(17 \cdot 52)$ \\
\hline$\geq 65$ & 36,497 & 28,540 & 65,037 & $10(27.40)$ & $10(35.04)$ & $21(32.29)$ & $3(8.22)$ & $4(14.01)$ & $7(10.76)$ \\
\hline Total & 253,633 & 248,947 & 502,580 & $70(27.60)$ & $90(36.15)$ & $160(31.83)$ & $21(8.28)$ & $42(16.87)$ & $63(12.53)$ \\
\hline
\end{tabular}

Values are presented as number (\%).

Table 3. The distribution of incidences of ulcerative colitis and Crohn's disease by years in Western Blacksea region

\begin{tabular}{|c|c|c|c|c|c|c|c|c|c|}
\hline \multirow[t]{2}{*}{ Year } & \multicolumn{3}{|c|}{$\begin{array}{l}\text { Upper than 15-year-old population } \\
\text { in Western Blacksea region }\end{array}$} & \multicolumn{3}{|c|}{$\begin{array}{c}\text { Ulcerative colitis } \\
\text { (incidence/100,000 person) }\end{array}$} & \multicolumn{3}{|c|}{$\begin{array}{c}\text { Crohn's disease } \\
\text { (incidence/100,00o person) }\end{array}$} \\
\hline & Female & Male & Total & Female & Male & Total & Female & Male & Total \\
\hline 2004 & 215,874 & 226,290 & 442,164 & $1(0.46)$ & o & $1(0.23)$ & $1(0.46)$ & $2(0.88)$ & $3(0.68)$ \\
\hline 2005 & 226,927 & 226,071 & 452,998 & $2(0.88)$ & $6(2.65)$ & $8(1.76)$ & $1(0.44)$ & 0 & $1(0.22)$ \\
\hline 2006 & 229,981 & 225,852 & 454,833 & $3(1.30)$ & $6(2.65)$ & $9(1.98)$ & o & $4(1.77)$ & $4(0.88)$ \\
\hline 2007 & 231,981 & 225,852 & 457,833 & $4(1.72)$ & $3(1.33)$ & $7(1.53)$ & o & $2(0.88)$ & $2(0.44)$ \\
\hline 2008 & 233,363 & 228,435 & 461,798 & $3(1.28)$ & $5(2.19)$ & $8(1.73)$ & o & $6(2.62)$ & $6(1.30)$ \\
\hline 2009 & 237,481 & 233,846 & 471,327 & $2(0.84)$ & $8(3.42)$ & $10(2.12)$ & $3(1.26)$ & $2(0.85)$ & $5(1.06)$ \\
\hline 2010 & 241,515 & 233,259 & 474,774 & $11(4 \cdot 55)$ & $10(4.28)$ & $21(4 \cdot 42)$ & $3(1.24)$ & $4(1.71)$ & $7(1.47)$ \\
\hline 2011 & 245,365 & 239,356 & 484,721 & $10(4.07)$ & $15(6.26)$ & $25(5.16)$ & $2(0.81)$ & $6(2.51)$ & $8(1.65)$ \\
\hline 2012 & 249,543 & 245,136 & 494,679 & $10(4.00)$ & $14(5 \cdot 71)$ & $24(4.85)$ & $5(2.00)$ & $3(1.22)$ & $8(1.62)$ \\
\hline 2013 & 253,633 & 248,947 & 502,580 & $10(3.94)$ & $13(5.22)$ & $23\left(4 \cdot 5^{8}\right)$ & $4\left(1.5^{8}\right)$ & $11(4 \cdot 42)$ & $15(2.98)$ \\
\hline \multicolumn{4}{|c|}{ Mean annual incidence (2004-2013) } & $5.6(2.30)$ & $8(3.37)$ & $13.6(2.84)$ & $1.9(0.78)$ & $4(1.69)$ & $5.9(1.23)$ \\
\hline
\end{tabular}

Values are presented as number (\%).

Table 4. The distribution of incidence of ulcerative colitis and Crohn's disease by age groups in Western Blacksea region in 2013

\begin{tabular}{|c|c|c|c|c|c|c|c|c|c|}
\hline \multirow[t]{2}{*}{ Age, yr } & \multicolumn{3}{|c|}{$\begin{array}{l}\text { Upper than 15-year-old population } \\
\text { in Western Blacksea region in } 2013\end{array}$} & \multicolumn{3}{|c|}{$\begin{array}{c}\text { Ulcerative colitis } \\
\text { (incidence/100,000 person) }\end{array}$} & \multicolumn{3}{|c|}{$\begin{array}{c}\text { Crohn's disease } \\
\text { (incidence/100,00o person) }\end{array}$} \\
\hline & Female & Male & Total & Female & Male & Total & Female & Male & Total \\
\hline $15-24$ & 50,338 & 51,576 & 101,914 & $2(3.97)$ & 1 (1.94) & $3(2.94)$ & $1(1.98)$ & o & $1(0.98)$ \\
\hline $25-34$ & 49,113 & 50,645 & $99,75^{8}$ & 0 & $5(9.87)$ & $5(5.01)$ & $1(2.04)$ & $3(5.92)$ & $4(4.01)$ \\
\hline $35-44$ & 46,043 & 47,336 & 93,379 & $5(10.86)$ & $4(8.45)$ & $9(9.64)$ & $1(2.17)$ & $1(2.11)$ & $2(2.14)$ \\
\hline $45-54$ & 39,868 & 39,834 & 79,702 & $\mathrm{o}$ & $1(2.51)$ & $1(1.25)$ & $1(2.51)$ & $1(2.51)$ & $2(2.51)$ \\
\hline $55-64$ & 31,774 & 31,016 & 62,790 & $2(6.29)$ & $2(6.45)$ & $4(6.37)$ & o & $2(6.45)$ & $2(3.18)$ \\
\hline$\geq 65$ & 36,497 & 28,540 & 65,034 & $1(2.74)$ & 0 & $1(1.58)$ & 0 & $4(14.01)$ & $4(6.15)$ \\
\hline
\end{tabular}

Values are presented as number (\%). 
The prevalence rate was calculated by the number of total cases to population under risk. SPSS version 20.0 programme (IBM Co., Armonk, NY, USA) was used for the statistical analysis. Chi-square test and Fischer exact test were used for the comparison of categorical variables, independent Student $t$ test and Mann-Whitney $U$ test were used for the comparison of continuous variables. STATA/MP software version 13.1 (StataCorp., College Station, TX, USA) was used to calculate and compare the incidence rates between the two periods (2004 to $2005 \mathrm{vs}$. 2011 to 2013). Significant $p$ value was accepted as $<0.05$.

Table 5. Urban and rural prevalences of Crohn's disease and ulcerative colitis in Western Blacksea region in 2013

\begin{tabular}{|c|c|c|c|c|c|c|c|c|c|}
\hline & \multicolumn{3}{|c|}{$\begin{array}{l}\text { Upper than 15-year-old population } \\
\text { in Western Blacksea region in } 2013\end{array}$} & \multicolumn{3}{|c|}{$\begin{array}{c}\text { Ulcerative colitis } \\
\text { (prevalence/100,000 person) }\end{array}$} & \multicolumn{3}{|c|}{$\begin{array}{c}\text { Crohn's disease } \\
\text { (prevalence/100,000 person) }\end{array}$} \\
\hline & Male & Female & Total & Male & Female & Total & Male & Female & Total \\
\hline Urban & 156,970 & 160,365 & 317,335 & $58(36.95)$ & $35(21.82)$ & $93(29.31)$ & $28(17.84)$ & $12(7.48)$ & $40(12.60)$ \\
\hline Rural & 91,977 & 93,268 & 185,245 & $32(34 \cdot 79)$ & $35(37.53)$ & $67(36.17)$ & $14(15.22)$ & $9(9.65)$ & $23(12.42)$ \\
\hline Total & 248,947 & 253,633 & 502,580 & $90(36.15)$ & $70(27.60)$ & $160(31.83)$ & $42(16.87)$ & $21(8.28)$ & $63(12.53)$ \\
\hline
\end{tabular}

Values are presented as number (\%).

Table 6. Distribution of urban and rural incidences of Crohn's disease and ulcerative colitis by years

\begin{tabular}{|c|c|c|c|c|c|c|c|c|c|c|}
\hline \multirow[t]{2}{*}{ Year } & \multirow{2}{*}{$\begin{array}{l}\text { Environ- } \\
\text { ment }\end{array}$} & \multicolumn{3}{|c|}{$\begin{array}{l}\text { Upper than 15-year-old popula- } \\
\text { tion in Western Blacksea region }\end{array}$} & \multicolumn{3}{|c|}{$\begin{array}{c}\text { Ulcerative colitis } \\
\text { (incidence/100,000 person) }\end{array}$} & \multicolumn{3}{|c|}{$\begin{array}{l}\text { Crohn's disease } \\
\text { (incidence/100,000 person) }\end{array}$} \\
\hline & & Male & Female & Total & Male & Female & Total & Male & Female & Total \\
\hline \multirow[t]{2}{*}{2004} & Urban & 109,679 & 97,086 & 206,765 & 0 & $1(1.03)$ & $1(0.48)$ & $1(0.91)$ & $1(1.03)$ & $2(0.97)$ \\
\hline & Rural & 116,611 & 118,788 & 235,399 & 0 & o & 0 & $1(0.86)$ & o & $1(0.42)$ \\
\hline \multirow[t]{2}{*}{2005} & Urban & 109,573 & 101,774 & 211,347 & $5(4 \cdot 56)$ & $1(0.98)$ & $6(2.84)$ & 0 & o & 0 \\
\hline & Rural & 116,498 & 124,523 & 241,021 & $1(0.86)$ & $1(0.80)$ & $2(0.83)$ & 0 & $1(0.80)$ & $1(0.41)$ \\
\hline \multirow[t]{2}{*}{2006} & Urban & 109,467 & 103,430 & 212,897 & $2(1.83)$ & $1(0.97)$ & $3(1.41)$ & $3(2.74)$ & o & $3(1.41)$ \\
\hline & Rural & 116,385 & 126,551 & 242,936 & $4(3.44)$ & $2\left(1.5^{8}\right)$ & $6(2.47)$ & $1(0.86)$ & o & $1(0.41)$ \\
\hline \multirow[t]{2}{*}{2007} & Urban & 120,415 & 123,121 & 243,536 & $3(2.49)$ & $3(2.44)$ & $6(2.46)$ & $2(1.66)$ & o & $2(0.82)$ \\
\hline & Rural & 105,437 & 108,860 & 214,297 & 0 & $1(0.92)$ & $1(0.47)$ & 0 & 0 & o \\
\hline \multirow[t]{2}{*}{2008} & Urban & 135,828 & 137,834 & 273,662 & $3(2.21)$ & $2(1.45)$ & $5(1.83)$ & $4(2.94)$ & o & $4(1.46)$ \\
\hline & Rural & 92,607 & 95,529 & 188,136 & $2(2.16)$ & $1(1.05)$ & $3(1.59)$ & $2(2.16)$ & 0 & $2(1.06)$ \\
\hline \multirow[t]{2}{*}{2009} & Urban & 139,706 & 140,868 & 280,574 & $7(5.01)$ & $1(0.71)$ & $8(2.85)$ & $1(0.72)$ & $2(1.42)$ & $3(1.07)$ \\
\hline & Rural & 94,140 & 96,613 & 190,753 & $1(1.06)$ & $1(1.04)$ & $2(1.05)$ & $1(1.06)$ & $1(1.04)$ & $2(1.05)$ \\
\hline \multirow[t]{2}{*}{2010} & Urban & 139,667 & 144,310 & 283,977 & $6(4.29)$ & $4(2.77)$ & $10(3.52)$ & $4(2.86)$ & $2(1.38)$ & $6(2.11)$ \\
\hline & Rural & 93,592 & 97,205 & 190,797 & $4(4.27)$ & $7(7.20)$ & $11(5.76)$ & 0 & $1(1.03)$ & $1(0.52)$ \\
\hline \multirow[t]{2}{*}{2011} & Urban & 145,614 & 147,995 & 293,609 & $14(9.61)$ & $7(4.73)$ & $21(7.15)$ & $4(2.75)$ & $2(1.35)$ & $6(2.04)$ \\
\hline & Rural & 93,742 & 97,370 & 191,112 & $1(1.07)$ & $3(3.08)$ & $4(2.09)$ & $2(2.13)$ & 0 & $2(1.05)$ \\
\hline \multirow[t]{2}{*}{2012} & Urban & 150,109 & 152,205 & 302,314 & $10(6.66)$ & $4(2.63)$ & $14(4.63)$ & $3(2.00)$ & $2(1.31)$ & $5(1.65)$ \\
\hline & Rural & 95,027 & 97,338 & 192,365 & $4(4.21)$ & $6(6.16)$ & $10(5.20)$ & 0 & $3(3.08)$ & $3(1.56)$ \\
\hline \multirow[t]{2}{*}{2013} & Urban & 156,970 & 160,365 & 317,335 & $3(1.91)$ & $3(1.87)$ & $6(1.89)$ & $4(2.55)$ & $3(1.87)$ & $7(2.21)$ \\
\hline & Rural & 91,977 & 93,268 & 185,245 & $10(10.87)$ & $7(7.51)$ & $17(9.18)$ & $7(7.61)$ & 1 (1.07) & $8(4 \cdot 32)$ \\
\hline \multirow{2}{*}{$\begin{array}{l}\text { Mean annual } \\
\text { incidence }\end{array}$} & Urban & & & & $5.3(3.86)$ & $2.7(1.96)$ & 8 (2.91) & $2.6(1.91)$ & $1.2(0.84)$ & $3.8(1.37)$ \\
\hline & Rural & & & & $2.7(2.79)$ & $2.9(2.94)$ & $5.6(2.86)$ & $1.4(1.47)$ & $0.7(0.70)$ & $2.1(1.08)$ \\
\hline
\end{tabular}




\section{RESULTS}

\section{Sociodemographical features}

The ratio of men was $56.2 \%$ and $66.6 \%$ for UC and CD respectively. The men/women ratio was 1.28 and 2.00 for UC and CD respectively. Though the men gender was predominant for both diseases, there was no significant difference between two groups $(p=0.727)$. The mean age was $46.1 \pm 14.5$ years in UC and $44.6 \pm 15.1$ years in $\mathrm{CD}(p=0.498)$. Eventhough the mean age is higher in $\mathrm{UC}$ when compared to $\mathrm{CD}$, the difference was not significant. Ninety-seven percent of patients were borned or populated in Western Blacksea region. Most of the patients were urbanite $(63.5 \%$ and $58.1 \%$ for $\mathrm{CD}$ and UC respectively). Despite the rate of married patients were high in both groups, there was no significant difference between diseases (79.3\% for CD and 87.5\% for UC, $p=0.296)$. Demographical features of the patients were summarized in Table 1.

\section{Prevalence and incidence rate}

According to the data obtained from Turkish Statistical Institute, the total number of population over 15 years old was 502,580, urban population was 317,335 and rural population was 185,245 in Western Blacksea region. Overall prevalence of UC and CD were $31.83 / 10^{5}$ and $12.53 / 10^{5}$ respectively. The prevalence was highest in the range of 35 to 44 years for UC and 25 to 34 years for CD. While the highest prevalence age-range remained unchanged in women, it was 45 to 54 years for UC and 55 to 64 for CD in men (Table 2). Although, mean annual incidence between 2004 and 2013 was higher in men than women, the overall incidence rate was $2.84 / 10^{5}$

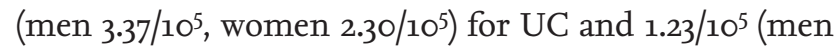
1.69/105, women $0.78 / 10^{5}$ ) for CD (Table 3). Mean annual incidance rates were $0.99 / 10^{5}$ for UC and $0.45 / 10^{5}$ for CD during the 2004 to 2005 period and $4.87 / 10^{5}$ for UC and $2.09 / 10^{5}$ for CD during the 2011 to 2013 period. These rates correspond to 4.83 times (95\% confidence interval [CI], 2.41 to 10.99) and 4.86 times (95\% CI, 1.66 to 18.25) increases in the incidence rates between the two periods for $\mathrm{UC}(p<0.0001)$ and for $\mathrm{CD}(p=0.0007)$, respectively. The increment of incidence of UC was more than CD. This increment in the incidence was higher in men when compared to women in both diseases (Fig. 1). When the incidence rate in 2013 was evaluated by age; the highest incidence in UC was seen in 35 to 44 years (9.64/105). While the highest incidence was observed between 25 to 34 years in men, it remained unchanged in women (9.87/10 $0^{5}$ and $10.86 / 10^{5}$ respectively). There was a second incidence peak in 35 to 44 years in male and 55 to 64 years in female. The highest incidence in $\mathrm{CD}$ was in $\geq 65$ years $\left(6.15 / 10^{5}\right)$. The highest incidence was in $\geq$ 65 years in men and it was in 45 to 54 years in women

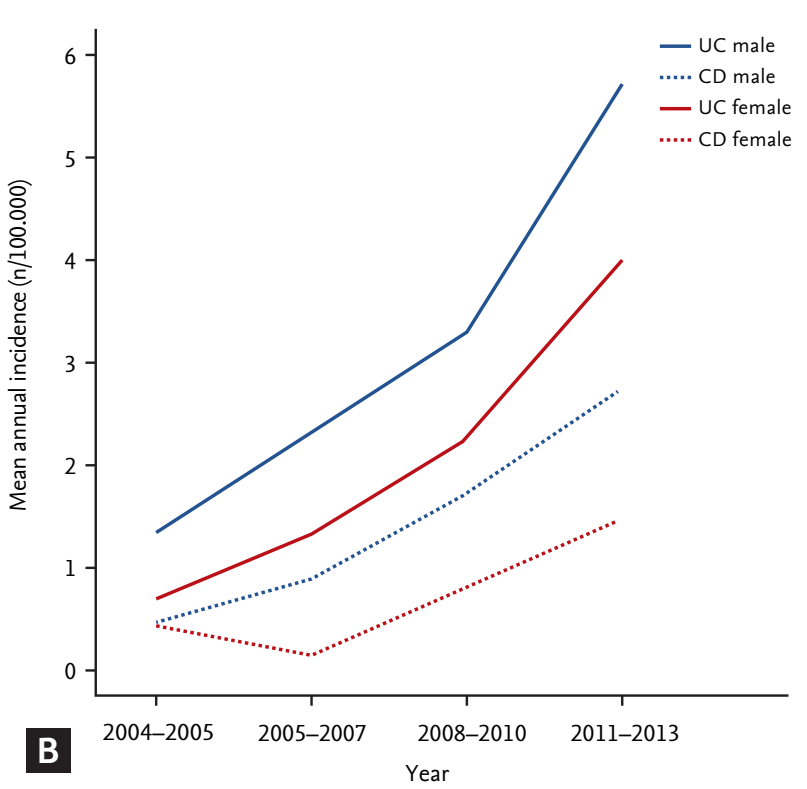

A

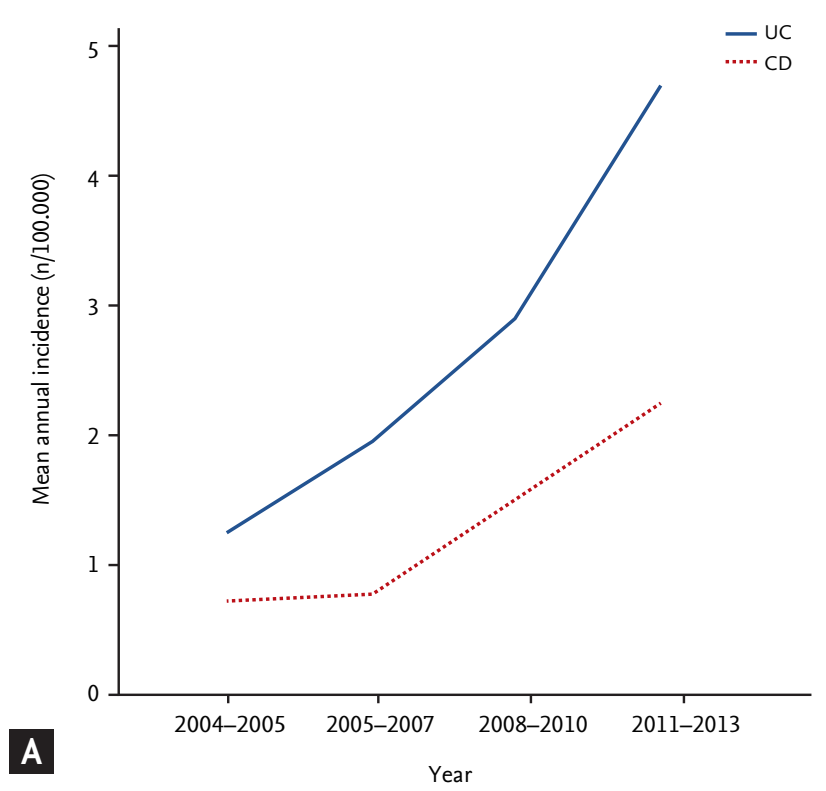

Figure 1. (A) Mean annual incidence rates and (B) gender-adjusted mean annual incidence rates of Crohn's disease (CD) and ulcerative colitis (UC) in 3-year periods between 2004 to 2013. 
(14.01/10 and 2.51/105, respectively) (Table 4).

The prevalence of $\mathrm{CD}$ was higher in urban population (rural 12.42/105, urban 12.60/105) and, the prevalence of UC was higher in rural population (rural 36.17/105, urban 29.31/105) (Table 5). The mean annual incidence rate was higher in urban population when compared to rural population in both of diseases. Generally, the mean annual incidence was higher in men than women, except the rural population in UC. The mean annual incidence of UC was $2.91 / 10^{5}$ (men 3.86/105, women $\left.1.96 / 10^{5}\right)$ and

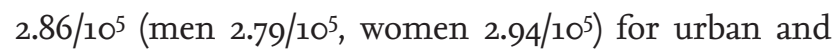
rural population respectively. The mean annual incidence of CD was 1.37/105 (men 1.91/105, women $0.84 / 10^{5}$ ) and $1.08 / 10^{5}$ (men $1.47 / 10^{5}$, women $0.70 / 10^{5}$ ) for urban and rural population respectively (Table 6 ). The mean annual incidence rate of UC was found $0.41 / 10^{5}$ in rural, and $1.66 / 10^{5}$ in urban population between 2004 to 2005 . This rate was increased to $5.49 / 10^{5}$ in rural and $4.56 / 10^{5}$ in
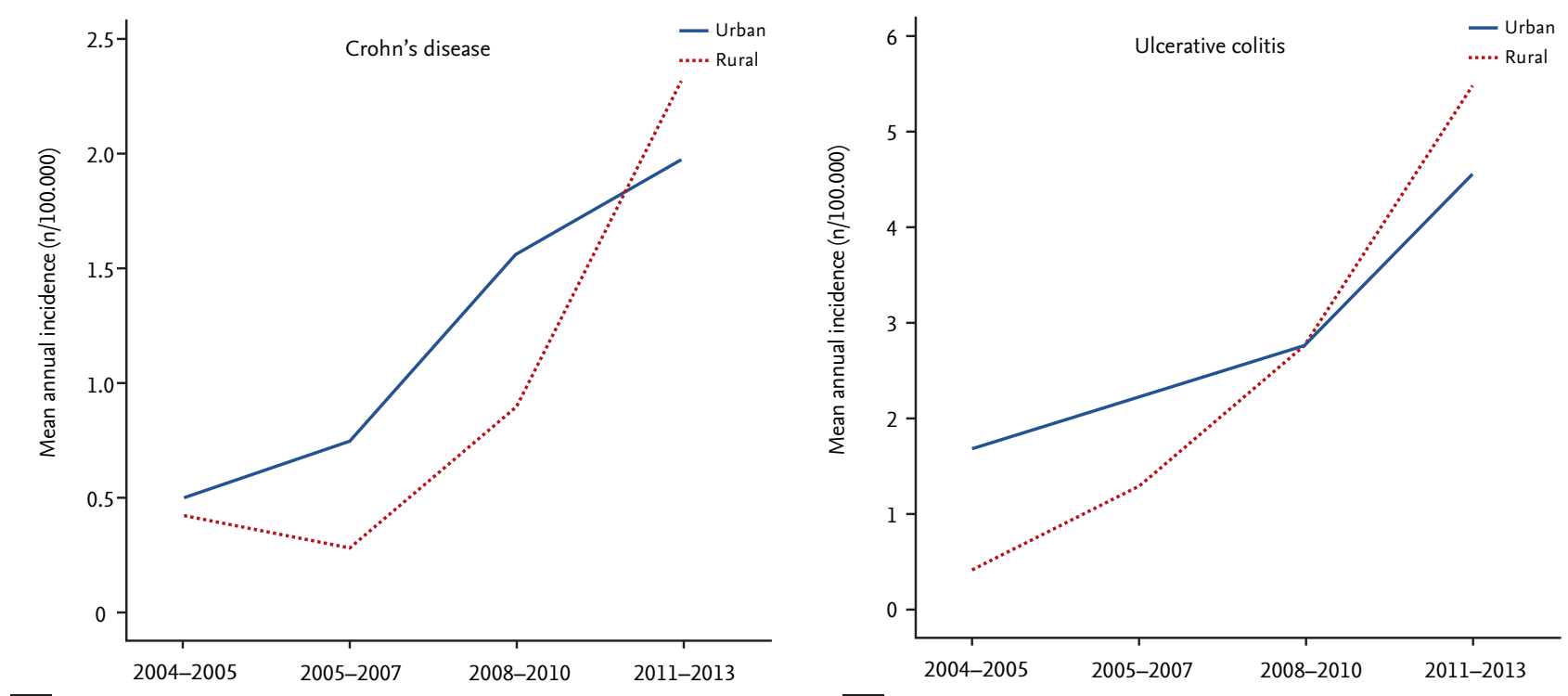

A

Year

B

Year
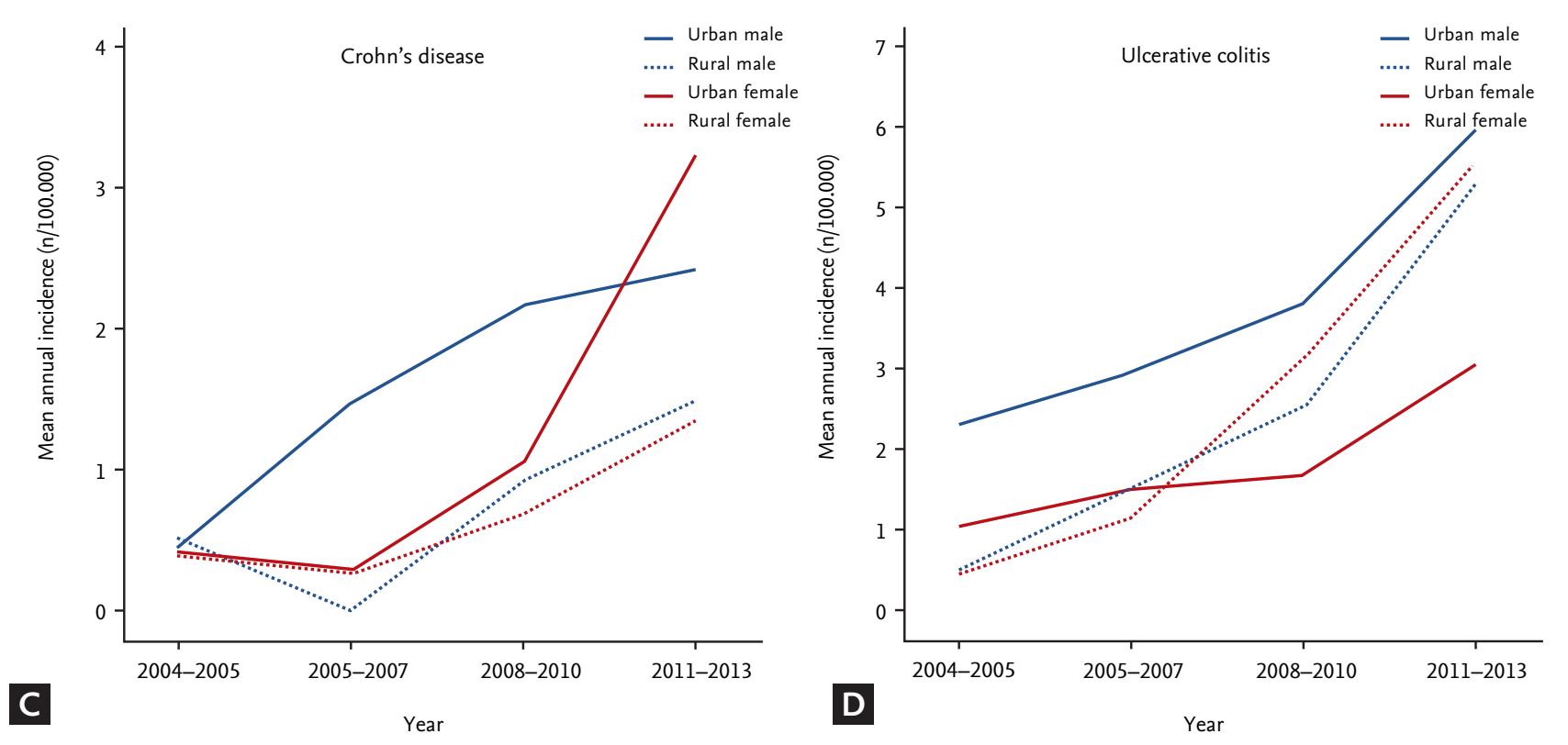

Figure 2. Mean annual incidence rates of (A) Crohn's disease (CD) and (B) ulcerative colitis (UC) in 3-years periods between 2004 to 2013 in urban and rural areas. Gender-adjusted mean incidence rates of (C) CD and (D) UC in 3-years periods between 2004 to 2013 in urban and rural areas. 


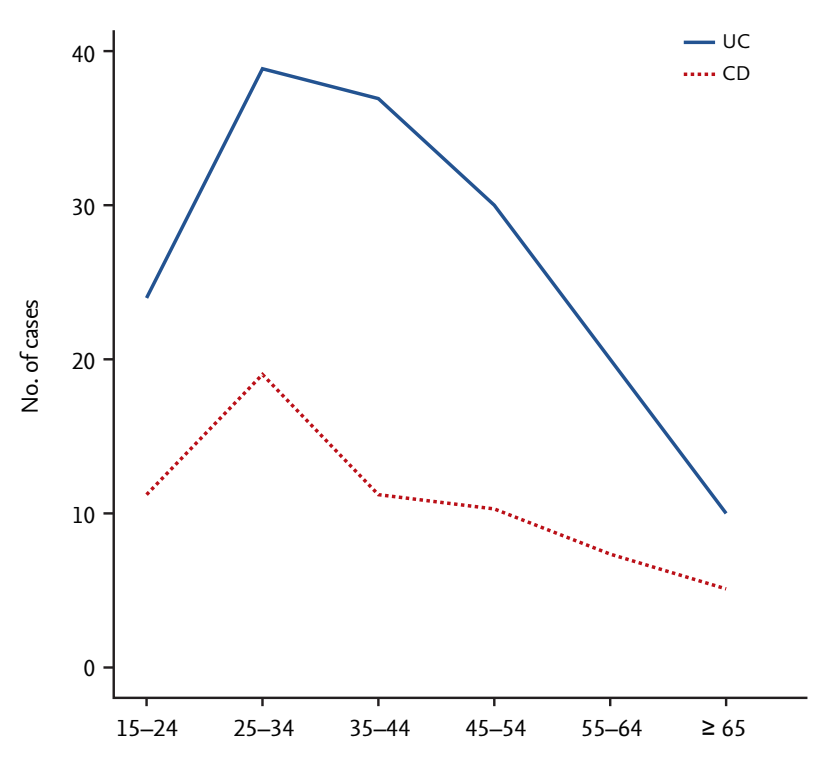

A

Age (yr)

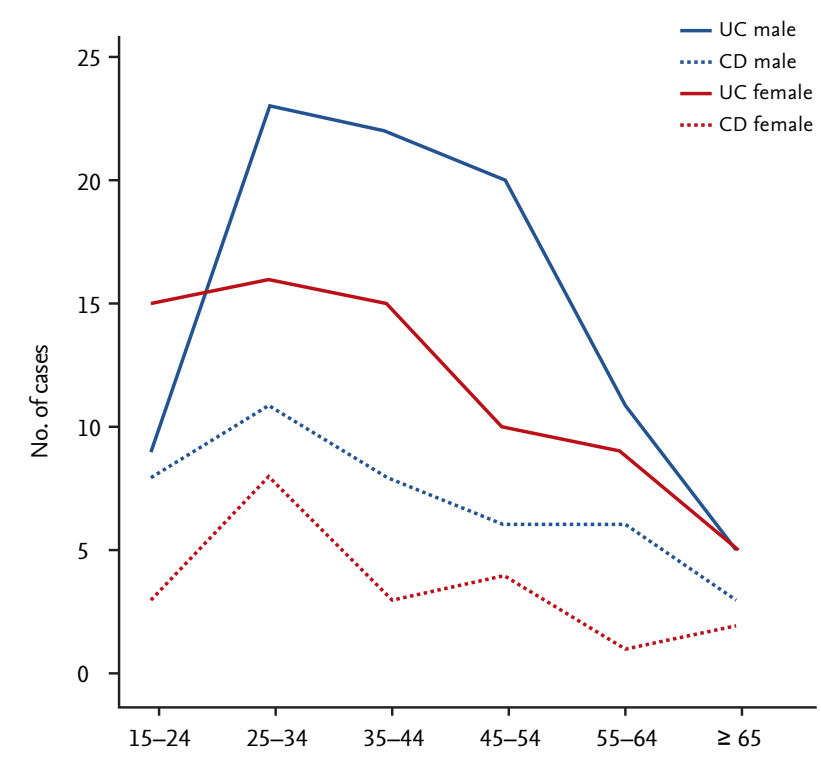

B

Age (yr)

Figure 3. The distribution of the patients with ulcerative colitis (UC) and Crohn's disease (CD) by (A) age of diagnosis and (B) gender-adjusted distribution of the patients.

urban population between 2011 to 2013. In the same way, the mean annual incidence rate of CD was $0.41 / 10^{5}$, and $0.48 / 10^{5}$ in rural and urban population respectively between 2004-2005, and this rate was increased to 2.31/105 and $1.97 / 10^{5}$ in rural and urban population respectively between 2011-2013. Incidence in rural population was increased faster than urban poulation in 10 years period in both of the diseases. So, the rural incidence was ahead of the urban incidence in the last 3 years period (Fig. $2 \mathrm{~A}$ and $2 \mathrm{~B}$ ). Contribution of men to escalation of incidence was more than women and this contribution was more prominent in terms of rural incidence for 10 years course in UC. In case of $\mathrm{CD}$, the incidence escalation was provided by men to a large extent (Fig. $2 \mathrm{C}$ and $2 \mathrm{D}$ ).

\section{Clinical features}

Though the age of diagnosis was higher in UC, there was no significant difference ( $40.5 \pm 14.2$ in UC, and 40.0 \pm 14.5 years in $\mathrm{CD}, p=0.831$ ). When evaluated by age, the mean age of diagnosis in men was higher than women, but the difference was not significant in both of the diseases (Table 1). Both UC, and CD were most frequently diagnosed at the same age range ( 25 to 34 years). When men and women were evaluated separately, the most frequent age of diagnosis did not change (Fig. 3).

\section{DISCUSSION}

In this study, the epidemiological features of UC and CD were evaluated in Western Blacksea region which has a homogenous population structure with a balanced distribution of rural and urban population. At the best of knowledge, there is no epidemiological trial after 2006 at this region. Our study is the first trial that evaluate the change of incidence of IBD in 10 years period.

The incidence and prevalence rate shows substantial differences in epidemiological trials that reported from different regions all over the world. While, the highest incidence and prevalence rates were reported from Canada and North Europe, the values were rather low in Asia. Incidence rate was reported as o to $19.2 / 10^{5}$ in

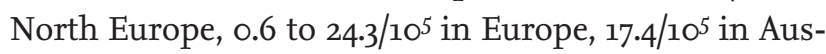
tralia, and 0.1 to 6.3/10 in Asia for UC, and 0.3 to $12.7 / 10^{5}$ in Europe, $\mathrm{O}$ to $20.2 / 10^{5}$ in North America, 29.3/10 Australia and 0.04 to $5 / 10^{5}$ in Asia and Middle East for CD [11,27-29]. Similarly prevalence rate was reported as 4.9 to $505 / 10^{5}$ in Europe, 37.5 to $248.6 / 10^{5}$ North America, and 4.9 to $168.3 / 10^{5}$ in Asia and Middle East for UC, and 0.6 to $322 / 10^{5}$ in Europe, 16.7 to $319 / 10^{5}$ in North America, and 0.88 to $67.9 / 10^{5}$ in Asia and Middle East for CD $[27,30,31]$. In the previous studies from Turkey, incidence 
rates differ between 0.74 to $4.4 / 10^{5}$ for UC and $2.2 / 10^{5}$ for CD. The prevalence rate is reported as 3.27 to $4.9 / 10^{5}$ and 1.18/10 respectively, for UC and CD [21-24]. The mean annual incidence rate of UC and $\mathrm{CD}$ was found as $2.84 / 10^{5}$ (0.23 to $5.16 / 10^{5}$ ) and $1.23 / 10^{5}$ (0.22 to $2.98 / 10^{5}$ ) respectively and the prevalence rate of $\mathrm{UC}$ and $\mathrm{CD}$ was found as $31.83 / 10^{5}$ and $12.53 / 10^{5}$ respectively in Western Blacksea region of Turkey in our study. In comparison, while the incidence values were observed similar to previous studies conducted in Turkey, the prevalence rates were significantly higher.

On the other hand, whereas the incidence and prevalence values display a similarity to Asian population, they were rather low according to the Western community. This can be resulted from the specific genetic background, unability to develope the industry to the level of Western countries and even to be an agricultural country. Also it can be due to the limitations of the study as the incidence and prevalence rates could be underestimated because of the patients with mild disease who did not refer any medical unit, the misdiagnosed patients or the patients who followed up in another city.

On the other hand, even though the incidence of IBD is very high in Western communities, it demonstrates a stable course, even a recent decline particularly in incidence of UC [10]. As the increase of incidence is ongoing in Eastern communities, the difference between East and West is closing up [29]. An escalation of incidence is seen in Turkish community in line with the increasing rates of incidence and prevalence in Eastern communities. According to our results, the mean annual incidence of UC was $0.99 / 10^{5}$ between 2004-2005 and, it increased to $4.87 / 10^{5}$ between 2011-2013 during 10 years period. Likewise, the incidence of CD also increased from $0.45 / 10^{5}$ to $2.09 / 10^{5}$. This rising trend show a similarity to the trend in Eastern communities [29].

Microbial exposure, sanitation, occupational choices, dietary habbits, life style, medicines, industrialization and air-pollution were evaluated as potential environmental risk factors for IBD [32]. Exposure to environmental risk factors are increasing with the industrialization in developing countries particularly in Turkey. So, escalation of incidence rates of IBD is seen in more industrialized regions $[7,8]$. Both the genetic factors, westernization of life style, industrialization and rising of the mentioned potential environmental risk factors can be the cause of the increased IBD incidence over 10 years period in Turkey.

As people grown up in urban area expose more environmental risk factors than the rurals in industrialized communities, IBD is experienced more frequently in urban areas [33-36]. IBD incidence was found higher in urban areas when compared to rural in all performed trials [29]. Prevalence of IBD for urban and rural areas was evaluated only in two studies among the trials conducted in Turkey and revealed that both of the diseases have higher prevalences in urban areas when compared to rural $[23,24]$. In our study, the prevalence was found higher in urban area for CD, and it was found higher in rural area for UC. When the mean annual incidence rate was evaluated, incidences of both diseases was found higher in urban area, consistent with the literature. When the escalation of incidence was evaluated for 10 years period of time, it is revealed that rising in rural was higher in distinct from the literature despite the incidence increased both in urban and rural areas. Even for the last 3 years period, escalation of the incidence in rural moved ahead of urban areas. The contribution of men to increased incidence is more than women particularly in rural area. Although there is no significant change in the population of our region, immigration from urban areas to rural may be the cause of this. On the other hand, westernization of life style and the popularization of convenience food, increasing number of plants in rural areas and the changing of occupational choices of people could contribute this result. The explanation for rising of incidence mainly in men can be the predominant role of men in active work life in rural areas. Women/men ratio was reported between 0.51 to 1.58 for UC and 0.34 to 1.65 for CD in previous trials [29]. An overall evaluation did not reveal any characteristic feature in terms of gender. In our study, though there was a men predominancy in both of the diseases, there was no significant difference between men and women consistent with the literature [29]. While the patients mostly diagnosed between 25 to 34 years old, prevalence peaked at younger ages ( 35 to 44 years in UC and 25 to 34 years in $\mathrm{CD}$ ) in both of the diseases as distinct from previous studies [29].

The overall increase of incidence in last century can be explained by the urbanization and increased exposure to environmental risk factors. However, increas- 
ing the awareness of doctors and community about the disease, attaining the opportunity to benefit more from the public health care service, crucial improvement in diagnostic methods recently and getting easy to reach colonoscopy can be the effective factors for the increased incidence in all world particularly in developed countries. Major limitation of our study, it is a hospital-based study. The patients with mild symptoms do not seek medical advise, consequently there are not any medical records. Because of that calculated incidence and prevalence rates were lower-estimated. There is a need of community based trials which can reveal the incidence and prevalence rates according to the relations between gene, environment and phenotype, in order to find out the key determinators of IBD in developed and developing countries.

In conclusion, the epidemiologic features of IBD for last decade was evaluated in Western Blacksea region. As well as the results are competent with Turkish literature, they confirm that Turkish population is resemble more likely to Eastern community in terms of IBD. In Western populations, though the incidence and prevalence rates stabilized in recent years, they are still very high. Although the incidence rates are going on to increase rapidly in countries that are not literally industrialized, developing countries like Turkey, they are still very low when compared to Western communities.

\section{KEY MESSAGE}

1. Turkish population is resemble more likely to Eastern community in terms of inflammatory bowel disease.

2. In Western populations, though the incidence and prevalence rates stabilized in recent years, they are still very high.

3. Although the incidence rates are going on to increase rapidly in countries that are not literally industrialized, developing countries like Turkey, they are still very low when compared to Western communities.

\section{Conflict of interest}

No potential conflict of interest relevant to this article was reported.

\section{Acknowledgments}

We special thank to Abdi Ibrahim Pharmacy for the help in language editing the manuscript.

\section{REFERENCES}

1. Mikhailov TA, Furner SE. Breastfeeding and genetic factors in the etiology of inflammatory bowel disease in children. World J Gastroenterol 2009;15:270-279.

2. Danese S, Sans M, Fiocchi C. Inflammatory bowel disease: the role of environmental factors. Autoimmun Rev 2004;3:394-400.

3. Podolsky DK. Inflammatory bowel disease. N Engl J Med 2002;347:417-429.

4. Jones DT, Osterman MT, Bewtra M, Lewis JD. Passive smoking and inflammatory bowel disease: a meta-analysis. Am J Gastroenterol 2008;103:2382-2393.

5. Hanauer SB. Inflammatory bowel disease: epidemiology, pathogenesis, and therapeutic opportunities. Inflamm Bowel Dis 2006;12 Suppl 1:S3-S9.

6. Loftus EV Jr, Sandborn WJ. Epidemiology of inflammatory bowel disease. Gastroenterol Clin North Am 2002;31:1-20.

7. Zheng JJ, Zhu XS, Huangfu Z, Gao ZX, Guo ZR, Wang Z. Crohn's disease in mainland China: a systematic analysis of 50 years of research. Chin J Dig Dis 2005;6:175-181.

8. Desai HG, Gupte PA. Increasing incidence of Crohn's disease in India: is it related to improved sanitation? Indian J Gastroenterol 2005;24:23-24.

9. Calkins BM, Mendeloff AI. Epidemiology of inflammatory bowel disease. Epidemiol Rev 1986;8:60-91.

10. Vind I, Riis L, Jess T, et al. Increasing incidences of inflammatory bowel disease and decreasing surgery rates in Copenhagen City and County, 2003-2005: a population-based study from the Danish Crohn colitis database. Am J Gastroenterol 2006;101:1274-1282.

11. Shivananda S, Lennard-Jones J, Logan R, et al. Incidence of inflammatory bowel disease across Europe: is there a difference between north and south? Results of the European Collaborative Study on Inflammatory Bowel Disease (EC-IBD). Gut 1996;39:690-697.

12. Logan RF. Inflammatory bowel disease incidence: up, down or unchanged? Gut 1998;42:309-311.

13. Loftus EV Jr, Silverstein MD, Sandborn WJ, Tremaine WJ, Harmsen WS, Zinsmeister AR. Crohn's disease in Olmsted County, Minnesota, 1940-1993: incidence, prevalence, 
and survival. Gastroenterology 1998;114:1161-1168.

14. Loftus EV Jr, Silverstein MD, Sandborn WJ, Tremaine WJ, Harmsen WS, Zinsmeister AR. Ulcerative colitis in Olmsted County, Minnesota, 1940-1993: incidence, prevalence, and survival. Gut 2000;46:336-343.

15. Loftus EV Jr. Clinical epidemiology of inflammatory bowel disease: incidence, prevalence, and environmental influences. Gastroenterology 2004;126:1504-1517.

16. Betteridge JD, Armbruster SP, Maydonovitch C, Veerappan GR. Inflammatory bowel disease prevalence by age, gender, race, and geographic location in the U.S. military health care population. Inflamm Bowel Dis 2013;19:14211427

17. Haug K, Schrumpf E, Barstad S, Fluge G, Halvorsen JF. Epidemiology of ulcerative colitis in western Norway. Scand J Gastroenterol 1988;23:517-522.

18. Yoshida Y, Murata Y. Inflammatory bowel disease in Japan: studies of epidemiology and etiopathogenesis. Med Clin North Am 1990;74:67-90.

19. Hiatt RA, Kaufman L. Epidemiology of inflammatory bowel disease in a defined northern California population. West J Med 1988;149:541-546.

20. Sonnenberg A, McCarty DJ, Jacobsen SJ. Geographic variation of inflammatory bowel disease within the United States. Gastroenterology 1991;100:143-149.

21. Ozin Y, Kilic MZ, Nadir I, et al. Clinical features of ulcerative colitis and Crohn's disease in Turkey. J Gastrointestin Liver Dis 2009;18:157-162.

22. Tozun N, Atug O, Imeryuz N, et al. Clinical characteristics of inflammatory bowel disease in Turkey: a multicenter epidemiologic survey. J Clin Gastroenterol 2009;43:51-57.

23. Tezel A, Dokmeci G, Eskiocak M, Umit H, Soylu AR. Epidemiological features of ulcerative colitis in Trakya, Turkey. J Int Med Res 2003;31:141-148.

24. Dagli U. Inflammatory bowel disease in Turkey. Proceedings of the Falk Symposium 159 on IBD 2007 Achievements in Research and Clinical Practice; 2007 May 4-5; Istanbul, Turkey. Falk Symposium Abstracts Book of Invited Lectures, 2008:25-26.

25. Dignass A, Eliakim R, Magro F, et al. Second European evidence-based consensus on the diagnosis and manage- ment of ulcerative colitis part 1: definitions and diagnosis. J Crohns Colitis 2012;6:965-990.

26. Van Assche G, Dignass A, Panes J, et al. The second European evidence-based Consensus on the diagnosis and management of Crohn's disease: definitions and diagnosis. J Crohns Colitis 2010;4:7-27.

27. Bernstein CN, Wajda A, Svenson LW, et al. The epidemiology of inflammatory bowel disease in Canada: a population-based study. Am J Gastroenterol 2006;101:1559-1568.

28. Lowe AM, Roy PO, B-Poulin M, et al. Epidemiology of Crohn's disease in Quebec, Canada. Inflamm Bowel Dis 2009;15:429-435.

29. Molodecky NA, Soon IS, Rabi DM, et al. Increasing incidence and prevalence of the inflammatory bowel diseases with time, based on systematic review. Gastroenterology 2012;142:46-54.

30. Bengtson MB, Solberg C, Aamodt G, et al. Familial aggregation in Crohn's disease and ulcerative colitis in a Norwegian population-based cohort followed for ten years. J Crohns Colitis 2009;3:92-99.

31. Cottone M, Renda MC, Mattaliano A, et al. Incidence of Crohn's disease and CARD15 mutation in a small township in Sicily. Eur J Epidemiol 2006;21:887-892.

32. Molodecky NA, Kaplan GG. Environmental risk factors for inflammatory bowel disease. Gastroenterol Hepatol ( $N$ Y) 2010;6:339-346.

33. Bernstein CN. Assessing environmental risk factors affecting the inflammatory bowel diseases: a joint workshop of the Crohn's \& Colitis Foundations of Canada and the USA. Inflamm Bowel Dis 2008;14:1139-1146.

34. Ekbom A, Adami HO, Helmick CG, Jonzon A, Zack MM. Perinatal risk factors for inflammatory bowel disease: a case-control study. Am J Epidemiol 1990;132:1111-1119.

35. Klement E, Lysy J, Hoshen M, Avitan M, Goldin E, Israeli E. Childhood hygiene is associated with the risk for inflammatory bowel disease: a population-based study. Am J Gastroenterol 2008;103:1775-1782.

36. Radon K, Windstetter D, Poluda AL, et al. Contact with farm animals in early life and juvenile inflammatory bowel disease: a case-control study. Pediatrics 2007;120:354361. 